\title{
Genetic Structure of Clavibacter michiganensis subsp. michiganensis Populations in Michigan Commercial Tomato Fields
}

L. M. Quesada-Ocampo, Visiting Research Associate, N. A. Landers, former Graduate Research Assistant, A. C. Lebeis, Undergraduate Research Assistant, D. W. Fulbright, Professor, and M. K. Hausbeck, Professor, Department of Plant Pathology, Michigan State University, East Lansing 48824

\begin{abstract}
Quesada-Ocampo, L. M., Landers, N. A., Lebeis, A. C., Fulbright, D. W., and Hausbeck, M. K. 2012. Genetic structure of Clavibacter michiganensis subsp. michiganensis populations in Michigan commercial tomato fields. Plant Dis. 96:788-796.

Clavibacter michiganensis subsp. michiganensis, causal agent of bacterial canker of tomato, is distinguished into four fingerprint types (A, $\mathrm{B}, \mathrm{C}$, and D) using BOX-polymerase chain reaction (PCR). To characterize the variation within the $C$. michiganensis subsp. michiganensis population in Michigan, 718 strains of C. michiganensis subsp. michiganensis were isolated from infected foliage and fruit collected from 14 and 9 Michigan commercial tomato fields in 1997 and 1998, respectively. The frequency of PCR types detected with BOX-PCR in all strains, and Bayesian cluster analysis, pairwise differentiation index comparisons, and genetic diversity estimates of 96 strains genotyped for six virulence-related genes revealed that $C$. michiganensis subsp.

michiganensis populations in Michigan tomato fields are geographically structured. A multilocus haplotype cladogram was also consistent with geographic stratification in C. michiganensis subsp. Michiganensis populations. Some regions had strains predominantly of only one PCR type or belonging mostly to one genetic cluster, while other regions presented more diversity of occurrence of PCR types and genetic clusters. Results derived from this study provide information about the genetic structure of $C$. michiganensis subsp. michiganensis populations in Michigan and genetic diversity of $C$. michiganensis subsp. michiganensis inocula, which is key in developing disease management strategies.
\end{abstract}

Clavibacter michiganensis subsp. michiganensis causes bacterial canker of tomato (50), a destructive disease that constitutes a threat to the tomato industry worldwide. C. michiganensis subsp. michiganensis was first reported in a tomato greenhouse in Michigan in 1909 and it is currently found in most tomato-growing regions $(52,54)$. Although $C$. michiganensis subsp. michiganensis can also infect other members of the family Solanaceae, including pepper, tomato is the only crop on which bacterial canker is economically important (40). Processingtomato growers in Michigan can suffer losses as high as $\$ 300,000$ per grower in a single year when conditions are favorable for disease (19). Bacterial canker symptoms include marginal leaf necrosis that may be bordered by chlorosis, fruit lesions (superficial white spots [3 to $6 \mathrm{~mm}$ ] that develop a necrotic center), plant wilting, stunting, reduced yields, and plant death (19).

The pathogen may be seedborne and overwinters in fields of the north-central United States for up to 2 years, providing a source of inocula during the growing season (15). C. michiganensis subsp. michiganensis can be transmitted to emerging seedlings (4) because it survives on the surface and in the layers of the seed coat $(5,54)$. C. michiganensis subsp. michiganensis populations thrive in humid greenhouses and may be spread to uninfected plants via overhead watering (19). In the Midwest, tomato transplants are grown in local greenhouses to later establish production fields. Greenhouse transplants can look healthy but may harbor bacterial populations that can cause severe disease symptoms in the field (19). Epiphytic populations on field plants may spread by water splashing, pesticide spraying, pruning, tying to stakes or trellises, sand blasting, and harvesting (15).

Corresponding author: M. K. Hausbeck, E-mail: hausbec1@msu.edu

* The $e$-Xtra logo stands for "electronic extra" and indicates that six supplemental tables are included in the online edition.

Accepted for publication 31 December 2011.

http://dx.doi.org/10.1094/PDIS-05-11-0402

(C) 2012 The American Phytopathological Society
Bacterial canker may be prevented by using certified plant material (23) or applying preventive antibiotic or copper compounds in the greenhouse and the field (60). No commercial varieties with effective resistance to $C$. michiganensis subsp. michiganensis have been developed to date (62). Characterizing the population structure and genetic diversity of $C$. michiganensis subsp. michiganensis is needed to determine possible inoculum sources and design effective disease management strategies. Repetitivesequence-based polymerase chain reaction (PCR) with a BOX primer (BOX-PCR) has been used to differentiate C. michiganensis subsp. michiganensis isolates into four PCR types (A, $\mathrm{B}, \mathrm{C}$, and D), which has provided valuable information about the genetic diversity of populations $(25,29,35,40)$. Several studies have tried to find associations between $C$. michiganensis subsp. michiganensis genotypes and tomato cultivar, region, or year of isolation using phylogenetic methods but no significant correlation has been detected $(8,40)$. Because genes involved in pathogen virulence have been shown to be under diversifying or positive selection that can obscure evolutionary relationships among individuals, neutrally evolving markers have been preferred for populations and evolutionary studies $(2,24,28,33,53)$. Nonetheless, several studies have recognized the potential usefulness of virulence-related genes to study plant pathogen populations because they can provide information on adaptation processes that can shape population structure $(25,39,43)$. The biological significance of the four PCR types detected using BOX-PCR is unknown but these markers are not strongly related to virulence because virulent as well as avirulent $C$. michiganensis subsp. michiganensis strains can have identical PCR types (29).

In this study, we aimed to investigate the genetic structure of $C$. michiganensis subsp. michiganensis populations in Michigan commercial tomato fields by using genotype data from BOX-PCR and six virulence-related genes. More specifically, we sought to (i) characterize the genetic variation of strains within and among fields using BOX-PCR fingerprinting, (ii) determine if we could detect population structure using Bayesian cluster analysis in a sample of isolates genotyped for six virulence-related genes and PCR type, and (iii) examine the distribution of genotypes from 
each inferred genetic cluster in the sample of isolates within predefined geographic and PCR type categories.

\section{Materials and Methods}

Sample collection. Foliar and fruit samples were collected from 14 and 9 commercial fields from four regions of Michigan in 1997 and 1998, respectively (Supplementary Table 1). Samples were arbitrarily collected according to cultivar or location in a field. One exception was a field in southwest Michigan (SW1/1/97), where individual plants were flagged and sampled along diagonal transects in July, August, and October 1997. Foliar samples consisted of two to three lower leaves exhibiting bacterial canker foliar symptoms. Fruit exhibiting bird's-eye lesions were collected. All samples were placed in plastic bags, transported in ice chests, and stored at $4^{\circ} \mathrm{C}$ for a maximum of 3 days before processing.

Pathogen isolation. Stems and leaves were chopped with a sterile single-edged razor blade, weighed, and homogenized for $2 \mathrm{~min}$ in a Lab-Blender 400 stomacher (Tekmar Co., Cincinnati, OH) in sterile phosphate buffer $(0.05 \mathrm{M}, \mathrm{pH} 7.4 ; 2 \mathrm{ml} / \mathrm{g}$ of plant tissue) amended with Tween-20 detergent $(0.02 \%)$. The plant extract (1 $\mathrm{ml}$ ) was mixed with $0.5 \mathrm{ml}$ of $40 \%$ glycerol ( $\mathrm{vol} / \mathrm{vol}$ ) and the resulting suspension stored at $-20^{\circ} \mathrm{C}(9)$. Each sample was subjected to a 10-fold serial dilution and plated onto nutrient broth yeast extract agar modified by omitting glucose (MNBY) and semiselective media for $C$. michiganensis subsp. michiganensis (SCM) (11), both amended with nalidixic acid (0.03 g/liter) and cycloheximide $(0.1 \mathrm{~g} / \mathrm{liter})$. The plant extract $(1 \mathrm{ml})$ was vortexed with $0.5 \mathrm{ml}$ of $40 \%$ glycerol and stored at $-20^{\circ} \mathrm{C}$. After a pure culture was obtained, each isolate was inoculated into $1 \mathrm{ml}$ of a sterile solution of distilled water (19\%), tryptic soy broth (78\%), and glycerol (3\%). Fruit lesions resembling bird's-eye lesions were probed using sterilized toothpicks directly under the surface of the lesion and the toothpicks were streaked on MNBY. Colonies resembling $C$. michiganensis subsp. michiganensis were stored at $-20^{\circ} \mathrm{C}$ in the C. michiganensis subsp. michiganensis culture collection maintained in the laboratory of Dr. Hausbeck at Michigan State University (MSU) and subjected to rep-PCR within a 2-year period as previously described (9).

Pathogen fingerprinting by rep-PCR. Strains were isolated from approximately 30 individual plant or fruit samples from each field and analyzed using the direct-colony rep-PCR method described by Louws et al. (29), with modifications. Isolates for PCR amplification were grown on either MNBY or SCM agar. Amplification was performed twice in a thermal cycler (Genemate-Techne, Princeton, NJ). Reactions included DNA AmpliTaq polymerase $(0.4 \mu \mathrm{l}$; Perkin Elmer, Norwalk, CT) and the BOXA1R (5'CTACGGCAAGGCGACGCTGACG-3') primer (32) (MSU Macromolecular Structure Facility, East Lansing, MI). PCR products (6 $\mu \mathrm{l})$ were analyzed by electrophoresis in $1.5 \%$ agarose gels in $0.5 \times$ Tris-acetate-EDTA (0.4 M Tris-acetate and $1 \mathrm{mM}$ EDTA, $\mathrm{pH} 8.0$ ) buffer at $4^{\circ} \mathrm{C}$ and $83 \mathrm{~V}$ for $13 \mathrm{~h}$. The gels were stained with ethidium bromide $(5 \mu \mathrm{g} / \mathrm{ml})$ for visualization and compared with a 100-bp ladder (Invitrogen, Carlsbad, CA). Genomic DNA isolated from strain 936 (29) of PCR type A was included as a positive control, and a negative control consisting of the reaction mixture without bacterial cells was included with each run. Gel photographs were analyzed by eye to determine the designation of PCR fingerprint types with the corresponding strains.

Primer design, amplification, and sequencing of genes. A sample of 96 isolates representing different PCR types found in four regions sampled was selected for population structure analysis using two plasmid genes known to be involved in virulence (celA and pat-1) as well as four chromosomal genes that may be related to virulence (ABCtransporter, mop, perforin, and phosphataseC) (Supplementary Table 5). Sequences for the selected six genes with virulence-related annotation were obtained from the $C$. michiganensis subsp. michiganensis genome (13) for primer design using the software Primer3 (51) (Supplementary Table 6). Cultures were grown in Luria-Bertani broth (Invitrogen) amended with nalidixic acid ( $0.03 \mathrm{~g} /$ liter $)$ and cycloheximide $(0.1 \mathrm{~g} / \mathrm{liter})$. Then, 1 $\mu \mathrm{l}$ of cells was transferred to PCR tubes containing $5 \mu \mathrm{l}$ of sterile water and heated at $95^{\circ} \mathrm{C}$ for $10 \mathrm{~min}$ in a programmable Eppendorf mastercycler ep systems thermal cycler (Eppendorf, Westbury, NY). The PCR mix was directly added to this suspension. Pairs of specific primers for each gene were used for PCR. Direct-colony PCR reactions were performed in a total volume of $25 \mu$ containing, $5 \mu \mathrm{l}$ of boiled bacterial cells, $5 \mu \mathrm{l}$ of $5 \times$ PCR reaction buffer (Invitrogen), $1.25 \mu \mathrm{l}$ of $25 \mathrm{mM} \mathrm{MgCl}{ }_{2}$ (Invitrogen), $0.5 \mu \mathrm{l}$ of 10 $\mathrm{mM}$ dNTP mix (Invitrogen), $1 \mu \mathrm{l}$ of each $10 \mu \mathrm{M}$ primer (MSU Macromolecular Structure Facility), $0.7 \mu$ of Platinum Taq DNA polymerase (Invitrogen), and $10.5 \mu \mathrm{l}$ of sterile water. The PCR reaction was performed in a programmable Eppendorf mastercycler ep systems thermal cycler (Eppendorf) under the following protocol: $3 \mathrm{~min}$ of denaturation at $94^{\circ} \mathrm{C}$; followed by 45 cycles at $94^{\circ} \mathrm{C}$ for $30 \mathrm{~s}$, annealing at $56^{\circ} \mathrm{C}$ for $30 \mathrm{~s}$, and extension at $72^{\circ} \mathrm{C}$ for $60 \mathrm{~s}$; with a final extension step of $10 \mathrm{~min}$ at $72^{\circ} \mathrm{C}$. PCR products were analyzed by electrophoresis in $2 \%$ (wt/vol) agarose gel in $0.5 \times$ Tris-borate-EDTA buffer (31), stained with ethidium bromide $(5 \mu \mathrm{g} / \mathrm{ml})$ for visualization, and compared with a 100-bp ladder (Invitrogen). Controls with extracted DNA and water instead of cells as a template were included. PCR products were cleaned for direct sequencing using the QIAquick PCR purification kit (Qiagen, Valencia, CA) following the manufacturer's instructions. Cycle sequencing reactions were done directly from the clean PCR products twice with the forward primer in the MSU Research Technology Support Facility (East Lansing, MI) using an ABI PRISM 3100 Genetic Analyzer.

Sequence analysis. Manual editing of base calls and sequence alignments were performed using Lasergene SeqMan Pro (version 8.0; DNASTAR Inc., Madison, WI). Alignments were exported as FASTA files and imported into MacClade (30) to generate NEXUS files required for subsequent analyses. Sequences were compared with sequence data publicly available by using nucleotide BLAST (1) to confirm that sequences corresponded to $C$. michiganensis subsp. michiganensis target genes. Sequences from each gene were analyzed individually and concatenated and collapsed into unique haplotypes using DnaSPv5 (27). Haplotypes found for each gene were deposited in GenBank under accession numbers HQ636574 to HQ636603. Base substitutions were classified as phylogenetically informative or uninformative, transitions or transversions, and synonymous or nonsynonymous substitutions using DnaSPv5.

DNA sequence variability, neutrality tests, recombination, and genealogies. Polymorphism, neutrality, and recombination analysis were performed for strains within geographic (northeast, north-central, southeast, and southwest) and PCR type (A, B, C, and D) categories using the program DnaSPv5. Sequence diversity estimates and statistics, including the number of segregating sites (s) and haplotypes (h), haplotype diversity (Hd) (41), Tajima's $\pi$ (55), average number of pairwise nucleotide differences (k) (55), and Watterson's theta $(\theta \mathrm{w})$ per gene (59), were calculated. Sequence variation was tested for deviations from neutrality by using $\mathrm{Fu}$ and Li's D and F and Tajima's D $(12,56)$. The recombination parameter (R) per gene (20) and minimum number of recombination events (RM) (21) were estimated. A neighbor-joining (NJ) tree was generated using MEGA4 (57) with default settings. Node support was assessed by running 1,000 bootstrap replicates. The NJ tree was imported into Dendroscope (22) to generate a radial cladogram of $C$. michiganensis subsp. michiganensis concatenated data haplotypes.

Population subdivision analysis. Population subdivision was assessed with the model-based Bayesian cluster algorithm implemented in Structure 2.3X (46). The values for burnin, chain replication, and lambda were set at 200,000, 100,000, and 1, respectively, based on results obtained in preliminary analyses. The optimal number of populations $(K)$ was determined by comparing posterior distribution likelihoods among three independent runs of $K=1$ to $K=10$ using the established parameters. Data included all genes individually coded as haplotypes, which were analyzed under the admixture model with correlated allele frequencies and without previous population information. Population structure 
figures with prior population information, obtained from the defined geographic and PCR type categories and sorted by Q, were generated using the Population Sorting Tool, a graphic editing program created in $\mathrm{R}$ (47) to visualize the distribution of clusters in predefined categories (J. J. Morrice, unpublished data). Genetic differentiation indexes $\left(\mathrm{F}_{\mathrm{ST}}\right)$ were calculated for data grouped by geographic and PCR type categories using DnaSPv5. Statistical significance was determined for each index by running 5,000 permutations $(\alpha=0.05)$.

\section{Results}

In total, 718 C. michiganensis subsp. michiganensis strains were obtained from sampled tomato fields located in southwest (SW), north-central (NC), northeast (NE), and southeast (SE) Michigan.
The most commonly observed $C$. michiganensis subsp. michiganensis strain in SW Michigan was type C (302 of a total of 319 strains), regardless of the number of cultivars present in a field (Supplementary Tables 1 and 2). In 1997, the SW fields containing only 'Mountain Spring' tomato (SW/1/1, SW/1/2, and SW/2/1) or Mountain Spring and Roma-type tomato (SW/3/1) harbored $C$. michiganensis subsp. michiganensis strains representing primarily the type C strains (27 to 30 strains/field) and a few type B strains (0 to 3 strains/field). Field SW/4/1/97 contained at least four cultivars; strains were mostly type C strains (20 strains), although type A strains (8 strains) were also present and two plants had a mix of type A and C strains. In 1998, two fields (SW/1/2 and SW/2/3), each containing only Mountain Spring tomato, harbored only type C strains.

A

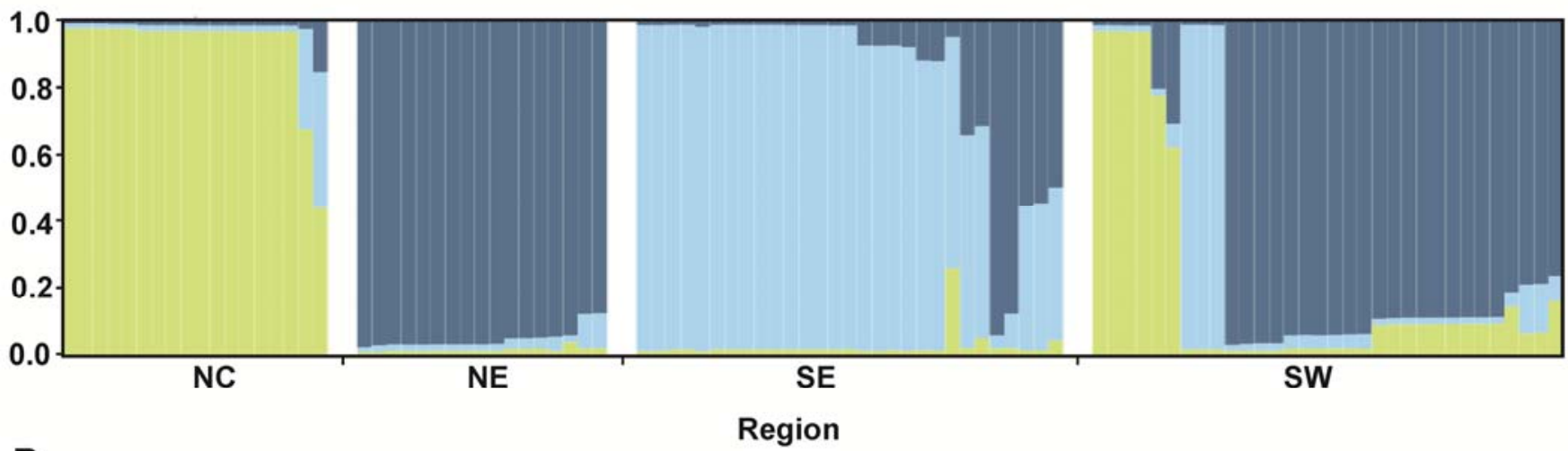

B

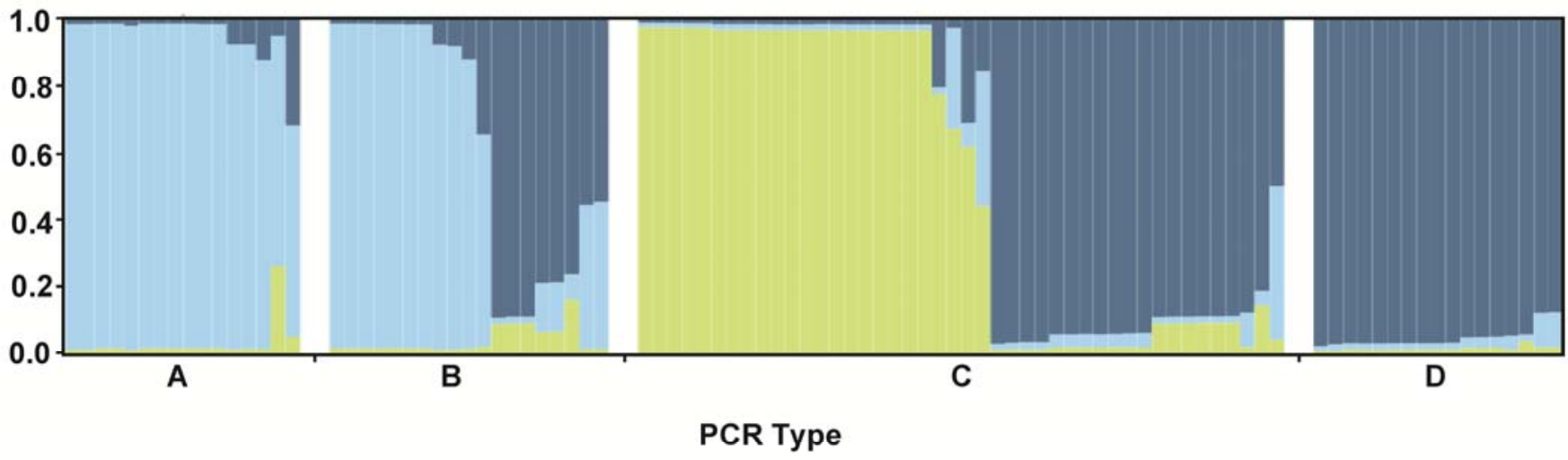

C

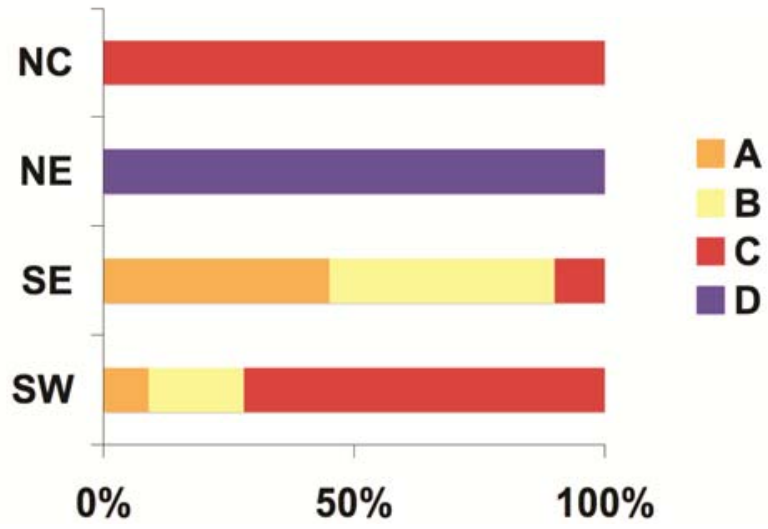

Fig. 1. Estimated population structure of 96 Clavibacter michiganensis subsp. michiganensis strains collected from tomato fields in Michigan. The same isolates are sorted by A, region and B, polymerase chain reaction (PCR) type. Each strain is represented by a single vertical bar, which is divided into colored segments with lengths representing proportional estimated membership of the isolate in each of the three clusters identified by Bayesian clustering. Colors correspond to clusters as follows: green $=$ cluster 1 , light blue = cluster 2, and dark blue = cluster 3. Region coding corresponds to NE, northeast; NC, north-central; SW, southwest; and SE, southeast. PCR type was assigned according to PCR using BOX primer. C, Percentage of each PCR type within each region. 
C. michiganensis subsp. michiganensis strains of type $\mathrm{C}$ were also the dominant type in yearly samplings of SW fields. When Mountain Spring tomato was planted in the same fumigated field in consecutive years (SW/1/2/97-98), the C fingerprint type was dominant in 1997 (29 strains) and 1998 (26 strains), with only one type B strain found in 1997 (Supplementary Table 3). The same trend of dominance of C-type C. michiganensis subsp. michiganensis strains was also observed in monthly samplings of SW fields. When a commercial Mountain Spring tomato field (SW/1/1/97) was sampled three times over the course of a growing season, the $C$. michiganensis subsp. michiganensis PCR types remained relatively stable and consisted primarily of type C (26 to 29 strains/sample time) and a few type B strains (0 to 3 strains/sample time) (Supplementary Table 4). Of the 31 plants sampled, 3 had both type B and C strains over the time sequence.

All strains from the only NE farm sampled (NE/1/1) were of type D, regardless of number of tomato cultivars or year of sampling. This farm was planted to 9 and 14 tomato cultivars during 1997 and 1998, respectively. In spring 1998, some fruit produced in a greenhouse on this grower's farm had symptoms of bird's-eye spots from which $C$. michiganensis subsp. michiganensis type D strains (GH1f, GH2-4, and GH3-5) were isolated.

The PCR type of $C$. michiganensis subsp. michiganensis strains sampled in four fields planted to one to three tomato cultivars in NC presented spatial variation. In 1997, the strains isolated from fields $(\mathrm{NC} / 1 / 1$ and $\mathrm{NC} / 1 / 2)$ were primarily type $\mathrm{C}(\geq 28)$, with a few type D strains $(\leq 2)$. Conversely, in 1998, the same grower's fields $(\mathrm{NC} / 1 / 3$ and $\mathrm{NC} / 1 / 4)$ contained mostly type D strains $(\geq 14)$ and a few type $\mathrm{C}$ strains $(\leq 9)$ (Table 1$)$.

Similar numbers of A, B, and C PCR types were found on multiple cultivars sampled from fields in SE Michigan. The obtained strains presented spatial and temporal variation in PCR type. In field SE/1/2 in 1997, the type A fingerprint was dominant (10 of 13), with one type $\mathrm{B}$ and two type $\mathrm{C}$ strains detected in low numbers. When the same field was sampled the following year, 12 type A strains and an increased number of type B strains (16 strains) were detected. Two plants in field SE/1/1/97 harbored mixed PCR type strains; one with $A$ and B and another with B and C. Field SE/3/1/97 contained one plant with mixed $\mathrm{A}$ and $\mathrm{C}$ fingerprint types and one plant with $\mathrm{B}$ with $\mathrm{C}$ types. In field SE/5/1/98, three plants had mixed A and $\mathrm{C}$ strains and five plants had mixed $\mathrm{B}$ and $\mathrm{C}$ strains.

A set of 96 strains was selected to perform population structure analyses using sequencing data from two plasmid virulence genes and four chromosomal genes that may be related to virulence. Sequence data from the six genes revealed 58 polymorphisms, 17 of which were parsimony informative (Table 2). Most of the nucleotide substitutions were nonsynonymous ( 35 of 58 ); both transitions (34 of 58) and transversions (23 of 58) were detected. All genes were polymorphic but pat-1 was more variable than other genes, as indicated by polymorphism analysis (Table 2) and diversity estimates (Table 1). Nonetheless, Hd estimates suggest that

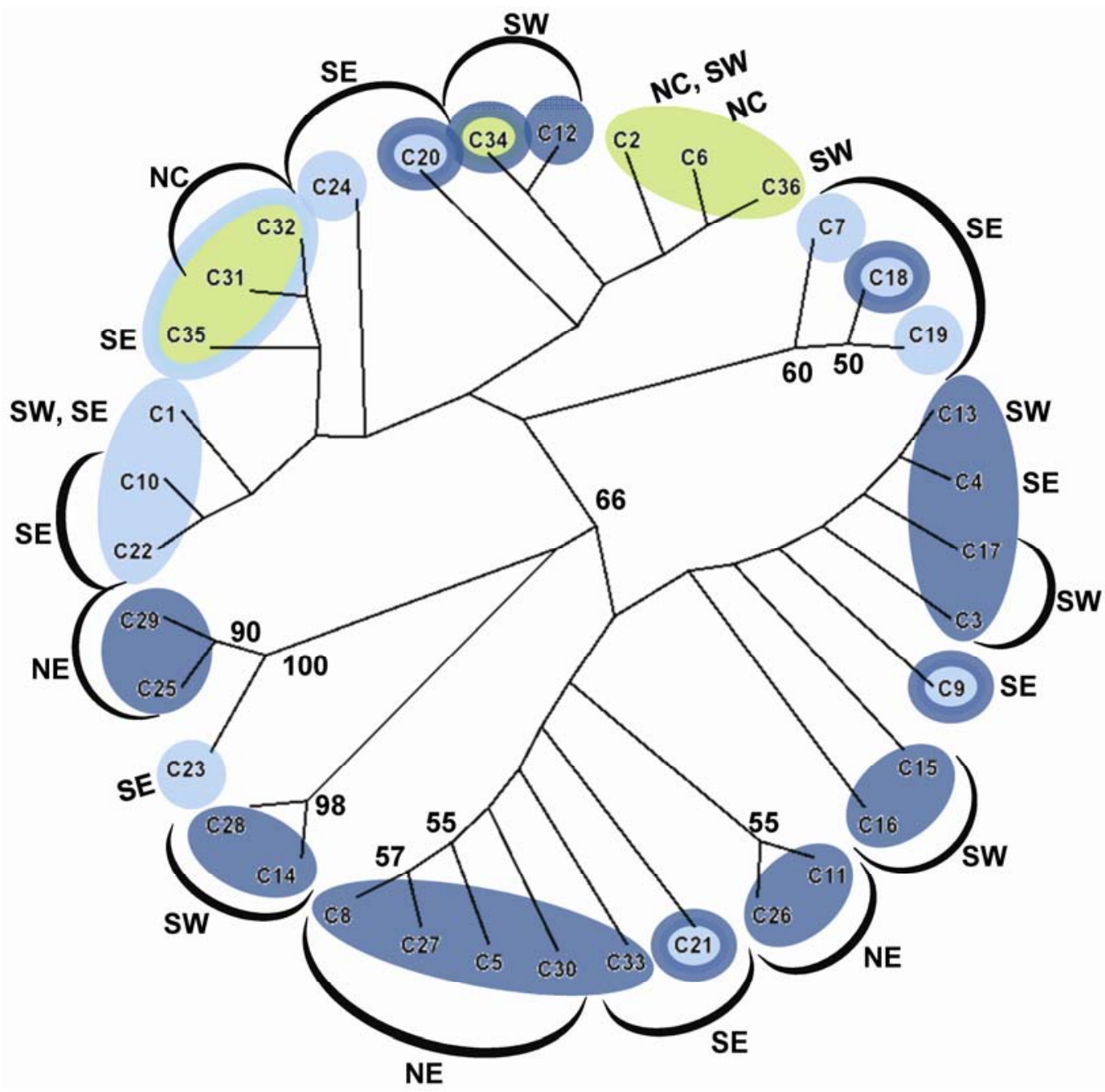

Fig. 2. Neighbor-joining radial cladogram of Clavibacter michiganensis subsp. michiganensis concatenated data haplotypes. Colored circles represent predominant membership of concatenated haplotypes in one or two genetic clusters. Colors correspond to clusters as follows: green $=$ cluster 1 , light blue $=$ cluster 2 , and dark blue $=$ cluster 3. Region coding corresponds to NE, northeast; NC, north-central; SW, southwest; and SE, southeast. Strains belonging to a particular concatenated haplotype are listed in Supplementary Table 5. Bootstrap support higher than $50 \%$ is indicated at the nodes. 
perforin contained the highest level of DNA polymorphism. Between 2 and 11 haplotypes were detected for all genes (Table 1). Unique haplotypes occurred in pat-1 (6\%), perforin (1\%), and phosphataseC $(2 \%)$. In general, all genes presented no or little recombination according to R and RM values. Tajima's D indicated a significant deviation from neutrality in pat-1 and perforin but all other genes presented no significant deviations from neutrality (Table 1).

Bayesian cluster analysis detected significant population structure by geography in the set of 96 strains, where some clusters occurred more frequently in some regions than others (Fig. 1A). High likelihoods were observed when the number of clusters was set to three $(K=3, \ln \mathrm{P}=-357 ; K=2, \ln \mathrm{P}=-433 ; K=4, \ln \mathrm{P}=-394$; Fig. $1 \mathrm{~A}$ and $\mathrm{B})$. Individual ancestry coefficients were highly consistent across replicate runs. The bar plots indicate that some strains are admixed, while others belong mostly to one particular cluster.

When the percentage of strains belonging to a PCR type was calculated within each region, geographic stratification was also apparent (Fig. 1C). Strains from NC and NE were PCR type C and $\mathrm{D}$, respectively, whereas strains from SE and SW presented PCR types A, B, and C. Strains from NC and NE belonged predominantly to cluster one and three, respectively (Fig. 1A). The NC category contained some admixed strains and NE strains presented little admixture. Most strains from SE were predominantly members of cluster two but some strains mostly from cluster three and admixed strains were also found. Strains from SW had the highest diversity of cluster occurrence from all regions, and strains predominantly from clusters one, two, and three were sampled as well as admixed strains. Diversity estimates for strains from NE were higher than for other regions, whereas strains from NC presented the lowest values for diversity indexes (Table 3). Diversity values for strains from SE and SW were high and comparable. $F_{\mathrm{ST}}$ estimates indicated high genetic differentiation among strains from all regions but NC strains had higher genetic differentiation values compared with other strains (Table 4). The highest differentiation occurred between strains from NE and NC and the lowest between strains from SE and SW.
When the PCR type categories were used as prior population information in the cluster analysis, some population structure was revealed in the selected 96 strains (Fig. 1B). Strains of PCR type A and D belonged mostly to clusters two and three, respectively. The PCR type A category contained some admixed strains, whereas the type D strains showed little admixture. Strains of PCR type B had predominant membership in clusters two and three, and also presented some admixed strains. The PCR type $\mathrm{C}$ category contained similar numbers of strains with predominant membership in clusters one and three, and some admixed strains were also present. Diversity estimates for strains of PCR type A presented the lowest values of all PCR type categories (Table 3 ). The highest diversity estimates were found in strains of PCR type B, followed by strains of type D. Strains of PCR type C presented moderate values of genetic diversity compared with strains of other PCR types. $\mathrm{F}_{\mathrm{ST}}$ values detected the highest genetic differentiation between strains of PCR type D and strains of all other types (Table 4). High genetic differentiation was found between strains of PCR types A and C, while moderate differentiation was detected between strains of PCR types B and C. $F_{S T}$ estimates indicated low genetic differentiation between strains of PCR types A and B.

When gene sequencing data was concatenated, 36 multilocus haplotypes were detected and $25 \%$ of these were unique. Three of the multilocus haplotypes (numbers 1, 3, and 7) included strains of two different PCR types, for a total of 39 multilocus haplotypes if PCR type is taken into account. The NJ radial cladogram of concatenated haplotypes showed three large clades of strains with a bootstrap support of $66 \%$ that were grouped by geography (Fig. 2). When Bayesian clusters and geographic origin of multilocus haplotypes were mapped on the cladogram, it was apparent that cladogram groups were consistent with results from population structure analysis, which detected geographic stratification in C. michiganensis subsp. michiganensis strains. Two clades contained strains from NE, SE, and SW, while the third clade contained strains from all regions. Smaller clades within larger clades were usually grouped according to genetic cluster membership or geographic origin. Three multilocus haplotypes $(\mathrm{C} 1, \mathrm{C} 2$, and $\mathrm{C} 4)$ in-

Table 1. Diversity estimates, neutrality tests, and recombination estimates for target plasmid and chromosomal genes in Clavibacter michiganensis subsp. michiganensis $^{\mathrm{a}}$

\begin{tabular}{|c|c|c|c|c|c|c|c|c|c|c|c|}
\hline \multirow[b]{2}{*}{ Target DNA } & \multicolumn{6}{|c|}{ Diversity estimates } & \multicolumn{2}{|c|}{$\begin{array}{c}\text { Recombination } \\
\text { estimates }\end{array}$} & \multicolumn{3}{|c|}{ Neutrality tests } \\
\hline & $\mathbf{s}$ & h & Hd & $\pi$ & $\theta w$ & $\mathbf{k}$ & $\mathbf{R}$ & $\mathbf{R M}$ & Tajima's D & Fu and Li's D & Fu and Li's F \\
\hline \multicolumn{12}{|l|}{ Plasmid } \\
\hline pat-1 & 45 & 11 & 0.271 & 0.006 & 8.761 & 2.548 & 0 & 0 & $-2.27 *$ & 0.717 & -0.578 \\
\hline \multicolumn{12}{|l|}{ Chromosome } \\
\hline ABCtransporter & 4 & 5 & 0.615 & 0.001 & 0.779 & 1.199 & 4 & 1 & 1.077 & 0.944 & 1.16 \\
\hline тор & 1 & 2 & 0.442 & 0.001 & 0.195 & 0.442 & 0 & 0 & 1.467 & 0.494 & 0.916 \\
\hline perforin & 2 & 4 & 0.663 & 0.001 & 0.389 & 0.926 & 5 & 1 & $2.134 *$ & 0.688 & 1.325 \\
\hline phosphataseC & 4 & 5 & 0.327 & 0.001 & 0.779 & 0.346 & 0 & 0 & -1.108 & -1.455 & -1.58 \\
\hline
\end{tabular}

a Symbols: $\mathrm{s}=$ number of segregating sites, $\mathrm{h}=$ number of haplotypes, $\mathrm{Hd}=$ haplotype diversity, $\pi=$ nucleotide diversity, $\theta \mathrm{w}=$ Watterson's theta estimator per gene from sequence, $\mathrm{k}=$ average number of nucleotide differences, $\mathrm{R}=$ recombination parameter, $\mathrm{RM}=$ minimum number of recombination events, and $*$ indicates significant at 0.05 .

Table 2. Polymorphism types for target plasmid and chromosome genes in Clavibacter michiganensis subsp. michiganensis

\begin{tabular}{|c|c|c|c|c|c|}
\hline Target DNA & Parsimony informative sites & Synonymous changes & Replacement changes & Transitions & Transversions \\
\hline \multicolumn{6}{|l|}{ Plasmid } \\
\hline celA & 2 & 1 & 1 & 2 & 0 \\
\hline pat-1 & 6 & 17 & 28 & 28 & 17 \\
\hline Subtotal & 8 & 18 & 29 & 30 & 17 \\
\hline \multicolumn{6}{|l|}{ Chromosome } \\
\hline ABCtransporter & 4 & 3 & 1 & 1 & 3 \\
\hline тор & 1 & 0 & 1 & 0 & 1 \\
\hline perforin & 2 & 0 & 2 & 2 & 0 \\
\hline phosphataseC & 2 & 1 & 2 & 1 & 2 \\
\hline Subtotal & 9 & 4 & 6 & 4 & 6 \\
\hline Total & 17 & 22 & 35 & 34 & 23 \\
\hline
\end{tabular}


cluded strains from two different regions. Otherwise, strains that shared a multilocus haplotype were found in the same region of sampling (Fig. 2). Eight multilocus haplotypes (C9, C18, C21, C20, C31, C32, C34, and C35) had membership in two different genetic clusters but the rest belonged mostly to one cluster.

\section{Discussion}

Bacterial canker is one of the most serious diseases affecting field and greenhouse-grown tomato. In order to study the population structure of $C$. michiganensis subsp. michiganensis populations in Michigan tomato fields, all strains obtained were genotyped using BOX-PCR, and a sample of 96 strains was selected for sequencing of six virulence-related genes. The frequency of PCR types detected with BOX-PCR for all strains and Bayesian cluster analysis, pairwise $\mathrm{F}_{\mathrm{ST}}$ comparisons, and genetic diversity estimates for 96 strains genotyped for six virulence-related genes revealed that $C$. michiganensis subsp. michiganensis populations in Michigan tomato fields are geographically structured. A multilocus haplotype cladogram was also consistent with geographic stratification in C. michiganensis subsp. michiganensis populations. Some regions had strains predominantly of only one PCR type or belonging mostly to one genetic cluster, while other regions presented more diversity of occurrence of PCR types and genetic clusters.

The dominant PCR type found in SW Michigan was type C but some type A and B strains were also found using BOX-PCR. Bayesian cluster analysis showed that most strains from SW belonged to cluster three but some strains from clusters one and two were also sampled. Regardless of the dominance of Mountain Spring in this region, SW presented strains from three PCR types $(\mathrm{A}, \mathrm{B}$, and $\mathrm{C})$ and all three genetic clusters. In a C. michiganensis subsp. michiganensis collection spanning 1981 to 1994, type C strains (11 strains) detected in SW fields were present at a higher incidence than type A (5 strains) and B (3 strains) strains, in agreement with our findings (29). Predominance of type C strains and strains from cluster three could be due to overwintering of inocula (6). In one SW field (SW/1/2) that was sampled in 1997 and 1998, symptom severity varied between years. In 1997, this field had young, newly established seedlings that were exhibiting severe wilting and eventually died, probably due to high numbers of $C$. michiganensis subsp. michiganensis on the seedlings at the time of transplanting (19). However, in 1998, disease symptoms in that same field were minor, consisting of marginal leaf necrosis on a few plants. Although overwintered host debris was not readily observed and plant beds were fumigated, the soil between the plant beds was not, leaving a possible source of inocula from infected plant debris. C. michiganensis subsp. michiganensis numbers on the transplants used to establish the field in 1998 could have been below the threshold required for more severe symptoms to occur during that year. Also, the fumigation efforts could have successfully reduced populations within the plant bed, leaving only inocula present from between plant beds.

Seedlings used to establish field SW/1/2 during 1997 and 1998 could have been contaminated with genetically similar strains, resulting in an increased sampling of type $\mathrm{C}$ strains. When recommendations to control bacterial canker on tomato are considered, a major focus has been on the source of inocula. Prior to 1990, Michigan growers routinely utilized transplants that had been grown in southern outdoor seedbeds. Infected transplants were recognized as a source of inocula after a severe bacterial canker outbreak in the Midwestern United States and Canada that was traced back to infected transplants from Georgia (14). Although Michigan growers have transitioned to local greenhouse-grown tomato transplants to avoid bacterial canker outbreaks, the disease has not been eliminated. The warm and humid environment of the

Table 3. Number of strains of Clavibacter michiganensis subsp. michiganensis and diversity estimates with strains grouped in geography and polymerase chain reaction (PCR) type categories ${ }^{\mathrm{a}}$

\begin{tabular}{|c|c|c|c|c|c|c|c|c|c|}
\hline \multirow[b]{2}{*}{ Category $^{\text {b }}$} & \multirow[b]{2}{*}{$N^{\mathrm{c}}$} & \multicolumn{2}{|c|}{ Hd } & \multicolumn{2}{|c|}{$\pi$} & \multicolumn{2}{|c|}{$\theta w$} & \multicolumn{2}{|c|}{$\mathbf{K}$} \\
\hline & & $\mathbf{P}$ & $\mathbf{C}$ & $\mathbf{P}$ & $\mathbf{C}$ & $\mathbf{P}$ & C & $\mathbf{P}$ & C \\
\hline \multicolumn{10}{|l|}{ Region } \\
\hline $\mathrm{NC}$ & 18 & 0 & 0.186 & 0 & 0 & 0 & 0.218 & 0 & 0.186 \\
\hline $\mathrm{NE}$ & 17 & 0.415 & 0.224 & 0.01 & 0 & 5.621 & 0.148 & 4.066 & 0.224 \\
\hline SE & 29 & 0.206 & 0.338 & 0.003 & 0.001 & 4.47 & 0.497 & 1.211 & 0.615 \\
\hline SW & 32 & 0.311 & 0.336 & 0.002 & 0.004 & 1.49 & 0.435 & 0.865 & 0.488 \\
\hline \multicolumn{10}{|l|}{ PCR type } \\
\hline A & 16 & 0.234 & 0.169 & 0.001 & 0.001 & 0.452 & 0.527 & 0.242 & 0.369 \\
\hline B & 19 & 0.366 & 0.418 & 0.006 & 0.002 & 5.722 & 0.572 & 2.416 & 0.731 \\
\hline $\mathrm{C}$ & 44 & 0.289 & 0.372 & 0.001 & 0.001 & 1.265 & 0.46 & 0.45 & 0.506 \\
\hline D & 17 & 0.415 & 0.224 & 0.01 & 0 & 5.621 & 0.148 & 4.066 & 0.224 \\
\hline
\end{tabular}

a Average for plasmid (P) and chromosomal (C) genes. $\mathrm{Hd}=$ haplotype diversity, $\pi=$ nucleotide diversity, $\theta \mathrm{w}=$ Watterson's theta estimator per gene from sequence, and $\mathrm{K}=$ average number of nucleotide differences.

${ }^{\mathrm{b}}$ Regions: NC, north-central; NE, northeast; SE, southeast, and SW, southwest. PCR type is designated according to PCR using BOX primer.

${ }^{\mathrm{c}}$ Number of strains.

Table 4. Genetic differentiation $\left(\mathrm{F}_{\mathrm{ST}}\right)$ estimates for Clavibacter michiganensis subsp. michiganensis with strains grouped in geography and polymerase chain reaction $(\mathrm{PCR})$ type categories

\begin{tabular}{|c|c|c|c|c|c|c|c|c|c|c|c|c|}
\hline \multirow[b]{3}{*}{ Category $^{b}$} & \multicolumn{12}{|c|}{$\mathbf{F}_{\mathbf{S T}}{ }^{\mathbf{a}}$} \\
\hline & \multicolumn{6}{|c|}{ Region } & \multicolumn{6}{|c|}{ PCR type } \\
\hline & \multicolumn{2}{|c|}{ NE } & \multicolumn{2}{|c|}{ SE } & \multicolumn{2}{|c|}{ SW } & \multicolumn{2}{|c|}{ B } & \multicolumn{2}{|c|}{ C } & \multicolumn{2}{|c|}{ D } \\
\hline Region & & & & & & & & & & & & \\
\hline $\mathrm{NC}$ & $0.456^{*}$ & $0.593 *$ & $0.482 *$ & $0.426^{*}$ & $0.256^{*}$ & $0.344 *$ & $\ldots$ & $\ldots$ & $\ldots$ & $\ldots$ & $\ldots$ & $\ldots$ \\
\hline $\mathrm{NE}$ & $\ldots$ & $\ldots$ & $0.333 *$ & $0.512 *$ & $0.321 *$ & $0.381 *$ & $\ldots$ & $\ldots$ & $\ldots$ & $\ldots$ & $\ldots$ & $\ldots$ \\
\hline SE & $\ldots$ & $\ldots$ & $\ldots$ & $\ldots$ & $0.208^{*}$ & $0.342 *$ & $\ldots$ & $\ldots$ & $\ldots$ & $\ldots$ & $\ldots$ & $\ldots$ \\
\hline \multicolumn{13}{|l|}{ PCR type } \\
\hline A & $\ldots$ & $\ldots$ & $\ldots$ & $\ldots$ & $\ldots$ & $\ldots$ & 0.023 & $0.135^{*}$ & $0.294 *$ & $0.451 *$ & $0.351 *$ & $0.527 *$ \\
\hline B & $\ldots$ & $\ldots$ & $\ldots$ & $\ldots$ & $\ldots$ & $\ldots$ & $\ldots$ & $\ldots$ & $0.171 *$ & $0.202 *$ & $0.289^{*}$ & $0.52 *$ \\
\hline $\mathrm{C}$ & $\ldots$ & $\ldots$ & $\ldots$ & $\ldots$ & $\ldots$ & $\ldots$ & $\ldots$ & $\ldots$ & $\ldots$ & $\ldots$ & $0.36^{*}$ & $0.4 *$ \\
\hline
\end{tabular}

${ }^{a}$ Average for plasmid (first column) and chromosomal (second column) genes; * indicates significant at 0.05 .

${ }^{\mathrm{b}}$ Regions: NC, north-central; NE, northeast; and SE, southeast. PCR type is designated according to PCR using BOX primer. 
greenhouse in addition to frequent overhead watering creates favorable growing conditions for bacterial populations (19); therefore, infected transplants continue to be a concern as a source of inocula in Michigan.

All samples from NE Michigan analyzed with BOX-PCR were PCR type D, and a sample of isolates genotyped for virulence-related genes were all members of cluster three, even though samples were collected from multiple tomato cultivars $(\leq 14)$. However, NE isolates analyzed with Bayesian clustering presented the highest diversity estimates from a sample of 96 strains from all regions. All NE samples were collected from the tomato grower with the largest production in this region, who produced tomato within a 5-acre plot that was rotated within a 20 -acre unfumigated field. Transplants used in the production fields were grown in greenhouses located on the farm but not adjacent to the production field. After the transplants were moved to the field, the grower used the greenhouse to produce full-sized plants and fruit from which C. michiganensis subsp. michiganensis strains type D were isolated in 1998. The greenhouse-grown plants did not show foliar symptoms but minimal fruit spotting could be observed. A recent study reported that plants are most susceptible to fruit infection at the flowering and small fruit stages of plant development (36). This suggests that the pathogen populations were high enough at the time of flowering to cause minimal fruit spotting, yet not high enough at an early stage of plant growth to cause severe symptoms on the mature plants. Sanitation practices in this greenhouse were lacking. The practice of extended greenhouse production coupled with a lack of field rotation created a situation in which bacterial populations may have survived on buried debris or alternative weed hosts in the field or the greenhouse, thereby providing a reservoir of $C$. michiganensis subsp. michiganensis strains type D and from cluster three from 1997 to 1998.

Type D strains were not found in the major fresh-market tomatogrowing regions of the SW or SE but they were found on another Michigan farm located in the NC region, approximately $129 \mathrm{~km}$ from the NE grower. The grower from the NC region had purchased transplants from the NE grower, although the exact years of purchase are unknown. The NC grower practiced short rotation $(<2$ years), did not fumigate the plant beds, and typically grew multiple cultivars $(\geq 3)$. Infected transplants that were grown in greenhouses of the NE grower likely harbored type D strains that were then transmitted to NC fields according to BOX-PCR analyses. Louws et al. (29) identified three type D strains from this farm from samples collected in 1994. The NC grower did not have type D strains exclusively, as did the NE grower, but also had type C strains. A shift in the incidence of the type D strains was observed from 1997 (3\%) to 1998 (80\%). If type D strains were introduced into NC due to the purchase of infected transplants from the grower in NE, their number may have increased during 1998 compared with 1997 due to the type of cultivars grown in this farm or simply because $C$. michiganensis subsp. michiganensis strains had time to spread throughout the field after their introduction.

Host selection is an important factor shaping the structure of plant pathogen populations (10); nonetheless, the effect of cultivars on population stratification of $C$. michiganensis subsp. michiganensis has not been elucidated. BOX-PCR analysis did not show strong associations of particular PCR types with tomato cultivar. Likewise, Bayesian cluster analysis did not indicate clear structuring of $C$. michiganensis subsp. michiganensis by tomato cultivar (data not shown). Type A strains have been described as being most frequently associated with processing cultivars (29). In our study, type A strains were only found in one SW Michigan field (SW/4/1/97) that included a processing cultivar. However, in this field, the type A strains were detected on both the processing cultivar and fresh-market cultivars. Louws et al. (29) described four C. michiganensis subsp. michiganensis strains obtained in 1994 from a SW Michigan field (SW/4) that contained processing cultivars; a type A strain was detected in this field and was the only type A strain detected in commercial fields in that region in 1994.
Farms growing diverse tomato cultivars (NE and SE) did not yield a higher diversity of PCR types or genetic clusters. However, diversity estimates did indicate higher genetic diversity in a sample of strains from NE and SE ( $\leq 14$ cultivars) than in the sample of strains from NC and SW ( $\leq 4$ cultivars). The diversity of tomato cultivars could have a diversifying effect in $C$. michiganensis subsp. michiganensis virulence genes, as has been noted in other pathogens $(2,24,28,33,53)$. Nevertheless, host stratification may be obscured by the detected geographic structure. Hence, future studies that analyze population structure by host nested within geography are needed to understand whether specific genetic clusters are associated to certain tomato cultivars. If associations between PCR type or genetic cluster with virulence or pathogenicity were found, fingerprinting information could be applied to determine what isolates are more virulent or pathogenic to particular tomato cultivars. This type of information may help to explain the presence of dominant fingerprint types and clusters in some of the fields and regions examined in this study. Louws, et al. (29) found a significant number $(30 \%)$ of avirulent type A strains, whereas type C strains were found to be predominantly virulent. Nonetheless, in our study, $16 \%$ of the type C strains were avirulent (data not shown). Understanding the diversity of C. michiganensis subsp. michiganensis is key to select virulent strains to use in host resistance screenings and develop resistant varieties.

Typical cultural practices of the SE region included long rotation ( $>3$ years), no fumigation, and a diversity of cultivars within and between farms. Field SE/4/1/98, containing 3 type A, 15 type B, and 33 type $\mathrm{C}$ strains, had never been planted to tomato before 1998. With the exception of three Florida-grown cultivars, all of the seedlings used to establish this field were grown in the grower's greenhouses that previously had been used only for production of flowering ornamentals and melon transplants. With the elimination of overwintered debris and greenhouse transplants as possible inoculum sources, seed or the Florida-grown transplants are the most likely source of inocula for the disease outbreak in this field. Disease symptoms were severe within some cultivars (wilting and stunting), yet minor within others (marginal necrosis). Seed from cultivars that were already contaminated in the greenhouse would likely exhibit severe symptoms in the field because the pathogen had time to reach threshold levels that result in disease symptoms (19). Spread from infected plants to uninfected plants in the greenhouse or field is suggested by the presence of bird's-eye fruit spotting on all cultivars. Ricker and Reidel (49) determined that secondary spread causes less severe symptoms of marginal necrosis and fruit spotting, and does not lead to yield loss. Nonetheless, fruit spotting can result in severe losses in freshmarket tomato.

Bayesian cluster analysis and $\mathrm{F}_{\mathrm{ST}}$ values of $\mathrm{SE}$ strains again indicated geographic structure in $C$. michiganensis subsp. michiganensis populations. Regardless of the high diversity of tomato cultivars planted $(\geq 4)$ and PCR types $(A, B$, and C) found in this region, most strains belonged predominantly to cluster two. Still, strains from clusters one and three were also sampled, which may explain the lower genetic differentiation between SE and SW, because strains from SW also presented PCR type and cluster occurrence similar to SE. The general geographic stratification observed in our study is probably due to the mode of transmission of $C$. michiganensis subsp. michiganensis. C. michiganensis subsp. michiganensis is not dispersed long-distance by wind, which would likely result in little or no geographic structuring because gene flow would homogenize populations (18). Because C. michiganensis subsp. michiganensis depends on human activity for longdistance transport $(6,14)$, the observed geographic structure indicated that gene flow between the studied regions is not common but it is possible. Once strains are introduced into a region, $C$. michiganensis subsp. michiganensis populations can survive on plant debris, depending on the agricultural practices of each farm, and serve as inocula for the next growing season $(6,7)$. Microbial populations that are spatially structured have been found to diverge quickly, given that gene flow between them is low (38). Establish- 
ing the spatial distribution of the three $C$. michiganensis subsp. michiganensis clusters detected in this study provides an initial map of population structure of $C$. michiganensis subsp. michiganensis in Michigan tomato-growing regions. Nonetheless, migration analysis using neutral markers would be useful in better understanding the historic movement of $C$. michiganensis subsp. michiganensis strains in Michigan, as has been done with other plant pathogens $(16,17)$.

When Bayesian cluster data for the sample of 96 C. michiganensis subsp. michiganensis strains was sorted by PCR type, strains seemed to be somewhat structured. Strains of type A and D were mostly members of cluster two and three, respectively. However, type D strains were all from NE; therefore, PCR type structure is probably an artifact of underlying geographic structure. This confounding effect of geographic stratification on structure by PCR type was also observed in type B strains that belonged mostly to cluster two when sampled in SE and to cluster three when isolated from plants in SW. Strains of PCR type C were somewhat structured because they included all strains with predominant membership in cluster one obtained from NC and SW.

Groups of multilocus haplotypes in the $\mathrm{NJ}$ radial cladogram were consistent with results from BOX-PCR and Bayesian clustering, which detected geographic stratification in $C$. michiganensis subsp. michiganensis strains. Strains that shared a multilocus haplotype were found in the same region of sampling and belonged mostly to one cluster. Population subdivision was also supported by the positive values for Tajima's D obtained for most genes (42). Other studies using genetic similarity dendrograms of C. michiganensis subsp. michiganensis populations in Israel did not identify clustering based on tomato cultivar, location, or year of isolation (8). It is desirable to perform population-based analysis such as Bayesian clustering to complement phylogenetic-based analyses commonly used in the study of bacterial populations. Several bacterial pathogens have been found to present recombination or horizontal transfer in their evolutionary histories, which could obscure phylogenetic relationships of strains $(3,44,61)$. The role of horizontal transfer in $C$. michiganensis subsp. michiganensis populations is unclear but could be contributing to population structuring due to the limited exchange of plasmids between bacterial strains restricted by geographic barriers (48). Recombination events in C. michiganensis subsp. michiganensis populations seem to be uncommon but detectable in our recombination estimates. Our observations of closely related multilocus haplotypes suggest that mutation events seem to be more important as a diversifying force in $C$. michiganensis subsp. michiganensis populations than recombination, as observed for other clonal organisms $(38,42,45)$.

BOX-PCR has been a useful technique for rapid and inexpensive identification of bacteria, which has yielded important epidemiological information of potential sources of inoculum and genetic variation in $C$. michiganensis subsp. michiganensis (29). Nonetheless, information about population divergence can be obtained by using sequencing data, in which polymorphisms are reproducible (58). Sequencing of housekeeping genes has been preferred for bacterial population studies because they are believed to evolve neutrally (34). However, sequencing of virulence-related genes can provide information on the evolution of virulence characteristics in bacterial pathogens and aid in the identification of strains with different virulence levels (42). The high variation detected in pat- 1 using diversity estimates has been observed in genes encoding virulence proteins (26). Significant and negative values for Tajima's D indicate an excess of low-frequency polymorphisms, a population expansion, or purifying selection for pat-1. The presence of pat-1 and celA has been found to be conserved in $C$. michiganensis subsp. michiganensis populations and is correlated with pathogenicity (25). The loss of plasmids harboring these genes is correlated with a reduction of virulence (37). In addition, perforin presented significant and positive values for Tajima's D, indicating low levels of high- and low-frequency polymorphisms, balancing selection or a recent population contraction. Hence, our findings support the role of pat-1 and perforin as viru- lence determinants. Further studies are required to demonstrate the role of both genes in virulence and functional differences associated with different alleles.

C. michiganensis subsp. michiganensis has been previously found in infected transplants, seed, weed hosts, and infected tomato debris that can serve as sources of initial inocula for some fields $(6,7,14)$. Our genetic analyses indicated that $C$. michiganensis subsp. michiganensis populations are geographically structured and that gene flow is rare but does occur among Michigan tomatogrowing regions included in this study. Nonetheless, studies on $C$. michiganensis subsp. michiganensis population structure that include information of pathogen diversity, phylogeny, and the partitioning of variation in space and time are still needed. Studies that compare the populations analyzed in our study with current populations found in Michigan tomato fields would provide valuable information about population stability through time and inoculum sources, which are key to develop disease management strategies. This study suggests that introduction of $C$. michiganensis subsp. michiganensis strains into tomato fields and greenhouses due to use of infected seed or transplants remains a concern for disease management; hence, growers are advised to use certified planting material and utilize preventive antibacterial sprays in both the greenhouse and the field (60). Crop rotation and sanitation of trellising stakes and greenhouse production facilities are also recommended to avoid overwintering of inocula.

\section{Acknowledgments}

This material is based upon work supported by the Mid-America Food Processors Association. We thank all the members of the Hausbeck lab for their valuable suggestions and help; J. J. Morrice for providing the Population Sorting Tool program to generate population structure figures; M. Mercier, M. Wood, and A. Pianosi for technical assistance; and L. Granke for critically reading the manuscript and assistance with figures.

\section{Literature Cited}

1. Altschul, S. F., Madden, T. L., Schaffer, A. A., Zhang, J., Zhang, Z., Miller, W., and Lipman, D. J. 1997. Gapped BLAST and PSI-BLAST: A new generation of protein database search programs. Nucleic Acids Res. 25:33893402 .

2. Anisimova, M., Bielawski, J., Dunn, K., and Yang, Z. 2007. Phylogenomic analysis of natural selection pressure in Streptococcus genomes. BMC Evol. Biol. 7:154.

3. Awadalla, P. 2002. The evolutionary genomics of pathogen recombination. Nat. Rev. Genet. 4:50-60.

4. Biggerstaff, C. M., Gleason, M. L., and Braun, E. J. 1999. Effect of soil moisture on tomato seed-to-seedling transmission of Clavibacter michiganensis subsp. michiganensis. (Abstr.) Phytopathology 89:S7.

5. Bryan, M. K. 1930. Studies on bacterial canker of tomato. J. Agric. 41:825851.

6. Chang, R. J., Ries, S. M., and Pataky, J. K. 1991. Dissemination of Clavibacter michiganensis subsp. michiganensis by practices used to produce tomato transplants. Phytopathology 81:1276-1281.

7. Chang, R. J., Ries, S. M., and Pataky, J. K. 1992. Local sources of Clavibacter michiganensis subsp. michiganensis in the development of bacterial canker on tomatoes. Phytopathology 82:553-560.

8. de Leon, L., Rodriguez, A., Llop, P., Lopez, M. M., and Siverio, F. 2009. Comparative study of genetic diversity of Clavibacter michiganensis subsp. michiganensis isolates from the Canary Islands by RAPD-PCR, BOX-PCR and AFLP. Plant Pathol. 58:862-871.

9. Dhingra, O. D., and Sinclari, J. B. 1995. Basic Plant Pathology Methods. CRC Press, Inc., Boca Raton, FL.

10. Escalante, A. A., Lal, A. A., and Ayala, F. J. 1998. Genetic polymorphism and natural selection in the malaria parasite Plasmodium falciparum. Genetics 149:189-202.

11. Fatmi, M., and Schaad, N. W. 1988. Semiselective agar medium for isolation of Clavibacter michiganensis subsp. michiganensis from tomato seed. Phytopathology 78:121-126.

12. Fu, Y. X., and Li, W. H. 1993. Statistical tests of neutrality of mutations. Genetics 133:693-709.

13. Gartemann, K.-H., Abt, B., Bekel, T., Burger, A., Engemann, J., Flugel, M., Gaigalat, L., Goesmann, A., Grafen, I., Kalinowski, J., Kaup, O., Kirchner, O., Krause, L., Linke, B., McHardy, A., Meyer, F., Pohle, S., Ruckert, C., Schneiker, S., Zellermann, E.-M., Puhler, A., Eichenlaub, R., Kaiser, O. and Bartels, D. 2008. The genome sequence of the tomato-pathogenic actinomycete Clavibacter michiganensis subsp. michiganensis NCPPB382 reveals a large island involved in pathogenicity. J. Bacteriol. 190:21382149 .

14. Gitaitis, R. D., Beaver, R. W., and Voloudakis, A. E. 1991. Detection of 
Clavibacter michiganensis subsp. michiganensis in symptomless tomato transplants. Plant Dis. 75:834-838.

15. Gleason, M. L., Gitaitis, R. D., and Ricker, M. D. 1993. Recent progress in understanding and controlling bacterial canker of tomato in eastern North America. Plant Dis. 77:1069-1076.

16. Gomez-Alpizar, L., Carbone, I., and Ristaino, J. B. 2007. An Andean origin of Phytophthora infestans inferred from mitochondrial and nuclear gene genealogies. Proc. Natl. Acad. Sci. USA 104:3306-3311.

17. Goss, E. M., Larsen, M., Chastagner, G. A., Givens, D. R., and Grunwald, N. J. 2009. Population genetic analysis infers migration pathways of Phytophthora ramorum in US nurseries. PLoS Pathog. 5:e10000583.

18. Hartl, D. L., and Clark, A. G. 1997. Principles of Population Genetics. Sinauer Associates, Inc., Sunderland, MA.

19. Hausbeck, M. K., Bell, J., Medina-Mora, C., Podolsky, R., and Fulbright, D. W. 2000. Effect of bactericides on population sizes and spread of Clavibacter michiganensis subsp. michiganensis on tomatoes in the greenhouse and on disease development and crop yields in the field. Phytopathology 90:38-44.

20. Hudson, R. R. 1987. Estimating the recombination parameter of a finite population model without selection. Genet. Res. 50:245-250.

21. Hudson, R. R., and Kaplan, N. L. 1985. Statistical properties of the number of recombination events in the history of a sample of DNA sequences. Genetics 111:147-164.

22. Huson, D., Richter, D., Rausch, C., Dezulian, T., Franz, M., and Rupp, R. 2007. Dendroscope: an interactive viewer for large phylogenetic trees. BMC Bioinf. 8:460.

23. Jahr, H., Bahro, R., Burger, A., Ahlemeyer, J., and Eichenlaub, R. 1999. Interactions between Clavibacter michiganensis and its host plants. Environmental Microbiology 1:113-118.

24. Johannesson, H., Vidal, P., Guarro, J., Herr, R. A., Cole, G. T., and Taylor, J. W. 2004. Positive directional selection in the proline-rich antigen (PRA) gene among the human pathogenic fungi Coccidioides immitis, C. posadasii and their closest relatives. Mol. Biol. Evol. 21:1134-1145.

25. Kleitman, F., Barash, I., Burger, A., Iraki, N., Falah, Y., Sessa, G., Weinthal, D., Chalupowicz, L., Gartemann, K.-H., Eichenlaub, R., and ManulisSasson, S. 2007. Characterization of a Clavibacter michiganensis subsp. michiganensis population in Israel. Eur. J. Plant Pathol. 121:463-475.

26. Ko, K. S., Hong, S. K., Lee, H. K., Park, M.-Y., and Kook, Y.-H. 2003. Molecular evolution of the dotA gene in Legionella pneumophila. J. Bacteriol. 185:6269-6277.

27. Librado, P., and Rozas, J. 2009. DnaSP v5: a software for comprehensive analysis of DNA polymorphism data. Bioinformatics 25:1451-1452.

28. Liu, Z., Bos, J. I. B., Armstrong, M., Whisson, S. C., da Cunha, L., TortoAlalibo, T., Win, J., Avrova, A. O., Wright, F., Birch, P. R. J., and Kamoun, S. 2004. Patterns of diversifying selection in the phytotoxin-like scr74 gene family of Phytophthora infestans. Mol. Biol. Evol. 22:659-672.

29. Louws, F. J., Bell, J., Medina-Mora, C., Smart, C. D., Opgenorth, D. C., Ishimaru, C. A., Hausbeck, M. K., de Bruijin, F. J., and Fulbright, D. W. 1998. rep-PCR mediated genomic fingerprinting: a rapid and effective method to identify Clavibacter michiganensis subsp. michiganensis Phytopathology 88:862-868.

30. Maddison, W. P., and Maddison, D. R. 2002. MacClade: Analysis of Phylogeny and Character Evolution. Sinauer Associates, Inc., Sunderland, MA.

31. Maniatis, T., Fritsch, E. F., and Sambrook, J. 1982. Molecular Cloning: A Laboratory Manual. Cold Spring Harbor Laboratory Press, Cold Spring Harbor, NY.

32. Martin, B., Humbert, O., Camara, M., Guenzi, E., Walker, J., Mitchell, T., Andrew, P., Prudhomme, M., Alloing, G., Hakenbeck, R., Morrison, D. A., Bounois, G. J., and Glaverys, J. P. 1992. A highly conserved repeated DNA element located in the chromosome of Streptococcus pneumoniae. Nucleic Acid Res. 20:3479-3483.

33. Matute, D. R., Quesada-Ocampo, L. M., Rauscher, J. T., and McEwen, J. G. 2008. Evidence for positive selection in putative virulence factors within the Paracoccidioides brasiliensis species complex. PLoS Neglected Trop. Dis. 2:e296.

34. McGregor, K. F., Spratt, B. G., Kalia, A., Bennett, A., Bilek, N., Beall, B., and Bessen, D. E. 2004. Multilocus sequence typing of Streptococcus pyogenes representing most known emm types and distinctions among subpopulation genetic structures. J. Bacteriol. 186:4285-4294.

35. Medina-Mora, C. 1999. Genetic Variation in Strains of Clavibacter michiganensis subsp. michiganensis and the Development of Bird's eye Fruit Lesions on Tomatoes. Michigan State University, East Lansing.

36. Medina-Mora, C., Hausbeck, M. K., and Fulbright, D. W. 2001. Bird's eye lesions of tomato fruit produced by aerosol and direct application of Clavibacter michiganensis subsp. michiganensis. Plant Dis. 85:88-91.

37. Meletzus, D., Bermpohl, A., Dreier, J., and Eichenlaub, R. 1993. Evidence for plasmid-encoded virulence factors in the phytopathogenic bacterium Clavibacter michiganensis subsp. michiganensis NCPPB382. J. Bacteriol. 175:2131-2136.

38. Miller, S. R., Purugganan, M. D., and Curtis, S. E. 2006. Molecular population genetics and phenotypic diversification of two populations of the thermophilic cyanobacterium Mastigocladus laminosus. Appl. Environ. Microbiol. 72:2793-2800.

39. Montarry, J., Corbiere, R., Lesueur, S., Glais, I., and Andrivon, D. 2006. Does selection by resistant hosts trigger local adaptation in plant-pathogen systems? J. Evol. Biol. 19:522-531.

40. Nazari, F., Niknam, G. R., Ghasemi, A., Taghavi, S. M., Momeni, H., and Torabi, S. 2007. An investigation on strains of Clavibacter michiganensis subsp. michiganensis in North and North West of Iran. J. Phytopathol. 155:563-569.

41. Nei, M. 1987. Molecular Evolutionary Genetics. Columbia University Press, New York.

42. Nightingale, K. K., Windham, K., and Wiedmann, M. 2005. Evolution and molecular phylogeny of Listeria monocytogenes isolated from human and animal Listeriosis cases and foods. J. Bacteriol. 187:5537-5551.

43. Parks, R., Carbone, I., Murphy, J. P., Marshall, D., and Cowger, C. 2008 Virulence structure of the Eastern U.S. wheat powdery mildew population. Plant Dis. 92:1074-1082.

44. Posada, D., and Crandall, K. A. 2001. Intraspecific gene genealogies: trees grafting into networks. Trends Ecol. Evol. 16:37-45.

45. Priest, F. G., Barker, M., Baillie, L. W. J., Holmes, E. C., and Maiden, M. C. J. 2004. Population structure and evolution of the Bacillus cereus group. J. Bacteriol. 186:7959-7970.

46. Pritchard, J. K., Stephens, M., and Donnelly, P. 2000. Inference of population structure using multilocus genotypic data. Genetics 155:945-959.

47. R-Development-Core-Team. 2008. R: A Language and Environment for Statistical Computing. R Foundation for Statistical Computing, Vienna.

48. Restrepo, S., and Verdier, V. 1997. Geographical differentiation of the population of Xanthomonas axonopodis pv. manihotis in Colombia. Appl. Environ. Microbiol. 63:4427-4434.

49. Ricker, M. D., and Riedel, R. M. 1993. Effect of secondary spread of Clavibacter michiganensis subsp. michiganensis on yield of northern processing tomatoes. Plant Dis. 77:364-366.

50. Rothwell, A. 1968. Bacterial canker of tomato caused by Corynebacterium michiganense (Smith) Jensen. Rhod. Agric. J. 1871:75-78.

51. Rozen, S., and Skaletsky, H. 2000. Primer3 on the WWW for general users and for biologist programmers. Methods Mol. Biol. 132:365-386.

52. Smith, E. F. 1910. A new tomato disease of economic importance. Science 31:794-796.

53. Stahl, E. A., and Bishop, J. G. 2000. Plant-pathogen arms races at the molecular level. Curr. Opin. Plant Biol. 3:299-304.

54. Strider, D. L. 1969. Page 110 in: Bacterial Canker of Tomato caused by Corynebacterium michiganense; a Literature Review and Bibliography. North Carolina Experiment Station.

55. Tajima, F. 1983. Evolutionary relationship of DNA sequences in finite populations. Genetics 105:437-460.

56. Tajima, F. 1989. Statistical method for testing the neutral mutation hypothesis by DNA Polymorphism. Genetics 123:585-595.

57. Tamura, K., Dudley, J., Nei, M., and Kumar, S. 2007. MEGA4: Molecular Evolutionary Genetics Analysis (MEGA) software version 4.0. Mol. Biol. Evol. 24:1596-1599.

58. van Berkum, P., Elia, P., and Eardly, B. D. 2006. Multilocus sequence typing as an approach for population analysis of Medicago-nodulating rhizobia. J. Bacteriol. 188:5570-5577.

59. Watterson, G. A. 1975. On the number of segregating sites in genetical models without recombination. Theor. Popul. Biol. 7:256-276.

60. Werner, N. A., Fulbright, D. W., Podolsky, R., Bell, J., and Hausbeck, M. K. 2002. Limiting populations and spread of Clavibacter michiganensis subsp. michiganensis on seedling tomatoes in the greenhouse. Plant Dis. 86:535542.

61. Wilson, D. J., Falush, D., and McVean, G. 2005. Germs, genomes and genealogies. Trends Ecol. Evol. 20:39-45.

62. Xu, X., Miller, S. A., Baysal-Gurel, F., Gartemann, K.-H., Eichenlaub, R., and Rajashekara, G. 2010. Bioluminescence imaging of Clavibacter michiganensis subsp. michiganensis infection of tomato seeds and plants. Appl. Environ. Microbiol. 76:3978-3988. 